\title{
The Effect of Project Based Learning on Level of Content Knowledge of Pre-Vocational Subject
}

\author{
Yang Guat See 1 \\ Abdullah Mat Rashid² \\ Ab Rahim Bakar² \\ ${ }^{1}$ Sekolah Menengah Kebangsaan Pandan Jaya, Kuala Lumpur, Malaysia \\ 2Universiti Putra Malaysia, Serdang, Malaysia; *Email: abmr@upm.edu.my
}

\section{Doi:10.5901/mjss.2015.v6n6s4p369}

\begin{abstract}
Project based learning (PoBL) offers promise as an instructional method that engaged student in school grounded through their experience with authentically learning. Findings from previous research shows results of positive effects on student such as create active, interesting and meaningful learning. The PoBL can be used as a teaching method in building 21 st century skills. This article reports the effect of PoBL towards students' level of knowledge in the Integrated Living Skills subject. This subject is a pre-vocational subject and has offers to students of lower secondary school education. The quasi experimental design was employed with the pre and post group design of two groups, the control group of 30 respondents and the treatment group of 33 respondents. The intervention executed took about eight weeks while the instruments used consist of a set of pre-test and post-test for one topic called Project Designs and Production in the subject. The finding shows that there is significant difference in mean scores between the treatment and control group. As a conclusion, the PoBL method can be practiced by teachers in the field of technical and vocational education as well as be made into a pedagogical practice besides traditional teaching in improving students' level of knowledge.
\end{abstract}

Keywords: Project based learning; 21st century skills; level of content knowledge; vocational subject; technical and vocational education

\section{Introduction}

Previous research has presented result of positive planning and management, teamwork, intrinsic motivation, creativity in learning, active communication skills in various subject including mathematics, science, language, and history. Limited empirical research conducted in teaching of technical and vocational subject. In Malaysia, the Kemahiran Hidup Bersepadu or Integrated Living Skills (ILS) is a pre-vocational subject that introduced to produced student who posses' basic skills education is hoped to provide opportunities to students who have the tendency in the education of science and technology to fill the workforce. The subject is introduced to students since level of lower secondary schools to produce students who possess basic skills and allow them to manage their live more productively besides being intellectually balanced. The ILS learning activities usually inculcate elements of technology, family, entrepreneurship, and good values integrally by implementing simple and applicable hands on learning for students. For example, students learn basic skills such as cooking, sewing, gardening, rearing animals, installing, building, servicing equipment and trading (Ministry of Education Malaysia, 2012).

Referred to the ILS syllabus, the objective of learning is clear to achieve certain levels in the cognitive (intellect), affective (emotion and spirit), and psychomotor (physical) aspects. Therefore the performance of students in KHB has to be measured through two different methods which are in written and practical tests. Written tests usually test the level of knowledge, memorisation, and comprehension of students on a topic. On the other hand, the practical test is used to test the skills and the competence of students in handling tasks. Therefore, this would gain a more wholesome learning process as it can strengthen students' intellect besides their soft and technical skills. KHB teachers need to use a variety of effective teaching approaches so that wholesome learning can be presented to students. Besides that, the selection of teaching methods also needs to fulfil the needs and desires of students in their learning.

The Ministry of Education Malaysia (2014) stated that the skills needed in teaching and learning in schools today has to be in line with the elements needed in the skills of the twenty first century. They are the: i) learning and innovative skills, ii) information, media and technology skills and; iii) living and career skills. This is in tandem with the elements 
needed in 21st century learning such as management, teamwork, technology and problem solving skills. According to Bell (2010) and Burlbaw, Ortwein and Williams (2009) this type of learning can be obtained using the PoBL method because: i) students learn independence through proper planning in every learning phase by making schedules during the initial phases of learning; ii) students learn socialising within the work place through group work and discussion; iii) students learn the usage of technology within the range of regulation of teachers based on correct and trusted sources, and; iv) students learn problem solving through real problems that are happening around them. Therefore, today education requires a learning strategy which focuses on the involvement of students in their learning. According to the Ministry of Education (2006), teachers still use lectures in their teaching and do not involve the role of students. This strategy of learning considers the teacher as the source of information with minimum student involvement (Effandi Zakaria \& Abd Razak, 2006).

Furthermore, with the current exam-oriented scenario, learning activities do not occur holistically, but only on several aspects of curriculum standard that are thought to be important to be masterd by students. If the students only memorise formulae and facts that are thought to be in the examination questions, this will bring adverse effects in the development of generic skills elements need to be mastered by students. A teaching method in the form of lectures are seen to be less effective in cultivating varieties of knowledge and skills within students in the technical and vocational fields. According to Schu Pyng and Mat Rashid (2014) and Ahmad Esa (2007), teaching using lecture style is not effective in providing the results as aimed by the country and the industrial parties.

The results for the Lower Secondary Exam or the Peperiksaan Menengah Rendah (PMR) for the year 2010 in state of Selangor recorded 2190 students who obtained E (Selangor State Education Department 2010), 2136 failed students in Perak (Perak State Education Department, 2010), and 1493 E students in Kelantan (Kelantan State Education Department, 2012). This number shows that many students are unable to achieve the minimum pass grade (grade D) in mastering this subject. Based on the report of the Ministry of Education Malaysia (2013), a few matters need to be given attention with regards to the weak performance in the lower secondary: i) students' failure in in mastering the questions in the form of long texts that needs comprehension, interpretation and reflection with real life, ii) many teachers stress on finishing the syllabus quickly while reducing the time for students to understand the concepts, and; iii) students lack of seriousness in learning.

Through this report, the teaching and learning process which is more student oriented needs to be taken into attention. Students need to be exposed to the real life learning situation, learn to identify available information and unavailable information as well as understand how to obtain new information with current technology. In this process, it is important for teachers to act as facilitators and not the problem solvers and givers of information only. This makes students the main players of learning. The second problem is attitude and responsibility. Students need to learn about their real roles in a community. Role-playing activities as tasks can expose students to their roles in the community. This process will expose them to the responsibility they need to face now and in the future.

According to Chon Min, Mat Rashid, and Nazri (2012), teacher need to be knowledgeable and competent in various methods and teaching approaches in order to encourage students' to think critically, creatively and innovatively. PoBL is one of the alternative teaching ways that can be used by KHB teachers to obtain holistic learning outcome. According to studies in other countries, PoBL is able to evaluate the ability of a student through a variety of evaluative components and this approach is more holistic compared to traditional teaching methods. A study by Pau Chai Hung (2009) reported that the PoBL helps students in understanding the learning topic which leads to the increase in student's achievement. Students who undergo PoBL are also reported to possess critical thinking, metacognition and higher effort compared to students who are taught via the traditional method (Bell, 2010). Findings by Grant (2011) showed that the students who are involved in the PoBL outperformed their counterparts who subscribed to the traditional learning methods.

Previous studies conducted found that PoBL is a good alternative for traditional learning (Yueyu Xu \& Wenqi Liu 2010; Helle, Tynjala \& Olkinuora 2006; Kaldi, Filippatou \& Govaris 2011) and can be applied in several fields of study (Holubova 2008; Grant 2009; Ravitz 2010). The method can be applied in mathematics, science and technical which stress on problem solving activities as a way to gain and apply knowledge. This method is also an effective curriculum to expand scientific, mathematics, and creativity capabilities. The principles of PoBL encourage optimal learning where it uses a multi-directional approach that involves teachers, peers, and professional workforce.

In America, Finland and Singapore, the project method is an old tradition that has been applied in the educational system (Markham, Lamer \& Ravitz 2003; Brodi 2008; Tung 2012). This approach has become the choice of the teaching workforce there because it can be manipulate to build critical thinking and problem solving skills (Tung, 2012). PoBL is used as a medium to improve real problem solving skills that occur around students' lives. Besides that, if compared to the element of learning, PoBL is in line with UNESCO's educational pillars; which are learning to know, learning to do, 
learning to live together, and learning to be. Therefore, many developed countries have applied the PoBL in their teaching and learning process.

Based on the findings in previous studies, the PoBL method can be practiced in schools especially in the field of technical and vocational education. Therefore, this study was conducted with the objective to examine the effects of PoBL towards students' level of content knowledge in the Integrated Living Skills subject. Specifically, the research hypotheses of the study are as follows:

$\mathrm{H}_{1}$ : There is no significant difference between the mean marks of the pre-test of the treatment group and pre-test of the control group.

$\mathrm{H}_{2}$ : There is no significant difference between the mean marks of the post-test of the treatment group and posttest of the control group.

$\mathrm{H}_{0}$ : There is no significant difference between the mean marks of the pre-test and post-test of the treatment group.

\section{Method}

This study was carried out in the Pandan Jaya National Secondary School for eight weeks using the quasi experimental method with the uneven pre and post group design. Available study samples in the classed were used as study samples. Form One students who take the Form 1 KHB subject were the samples. 63 respondents were involved where 33 students were in the treatment group and 30 students were in the control group.

The treatment group received the PoBL learning method while the control group received the traditional lecture style learning method. A teacher was briefed on the intervention of the study and has agreed to teach the same topic in the determined period of time for both study groups. However, the teacher is not informed about the control and treatment group. The data collection process is shown in Figure 1.

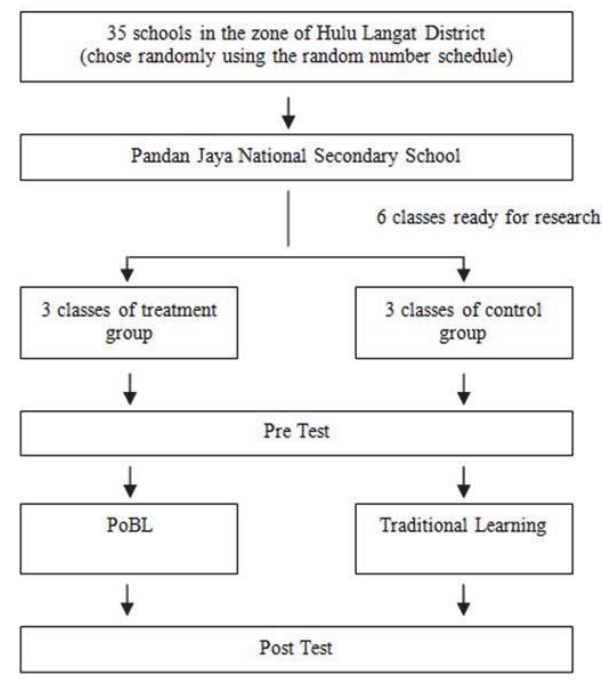

Figure 1: Process of Data Collection

The research instrument consists of a set of pre and post-test questions. All the instruments have obtained content validity from KHB expert teachers and lecturers in the field of research. Both groups sat for the pre-test before learning the Project Design and Production or Reka Bentuk dan Penghasilan Projeck (RBPP) topic. The pre-test was used to ensure the similarity in knowledge level for both groups. The post-test, on the other hand, was used to compare the marks score obtained by both groups. The tests sets consist of questions that test the level of knowledge, memory and comprehension of students. Both tests are scored and categorised into mark grades which were then analysed using the SPSS software.

The intervention programme used in this study is based on Moursund's model (1999) which was improved by Erdem (2002). This model encompasses 11 levels of learning as shown in Table 1. 
Table 1: Levels of Project based Learning

\begin{tabular}{cl}
\hline Level & Activity \\
\hline 1 & Identify teaching and learning objectives. \\
2 & Identify and determine problems that students need to solve. \\
3 & Identify reporting features and presentation format. \\
4 & Identify evaluation criteria. \\
5 & Form groups. \\
6 & Identify guiding questions brought suggested by teachers. \\
7 & Plan the information collecting process. \\
8 & Design the work schedule. \\
9 & Identify the checklist. \\
10 & Collect, arrange and report information. \\
11 & Present the results and conclusions. \\
\hline
\end{tabular}

Source: Moursund (1999) and Erdem (2002)

The PoBL intervention module programme implementation procedure consists of six main steps as shown in figure 2 . Throughout the teaching and learning process, the teacher acts as a facilitator and drives students with guiding questions. Students played the main role and are responsible towards their self-learning processes. A few skills that are trained throughout the PoBL intervention are as follows:

i. Knowledge on basic project design

ii. Skills in solving problems as a group

iii. Using sources effectively to search for information

iv. Communication skills

v. Teamwork

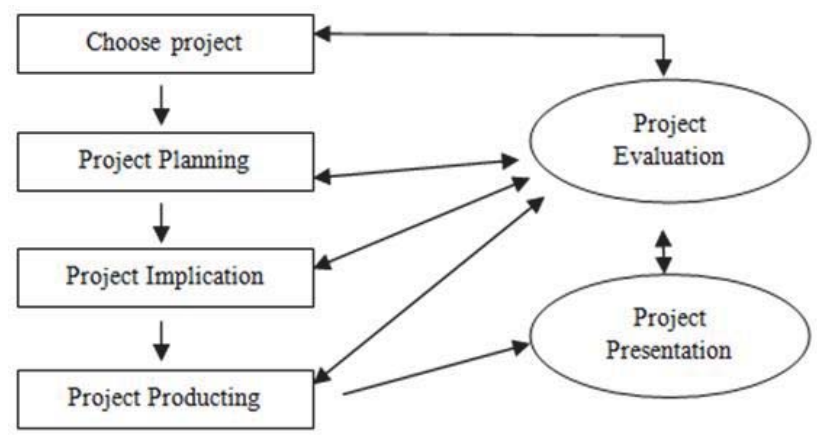

Figure 2: The intervention programme module procedure

Source: Wu \& Meng (2010)

\section{Findings}

$\mathrm{Ho}_{0}$ : there is no significant difference between the mean marks of the treatment group pre-test and the control group pretest.

Table 2 shows the comparison of marks obtained by respondents from both treatment and control groups. No students obtained A or B in the pre-tests for both groups. 20 students obtained grade $E(60.6 \%)$ in the treatment group, while 21 students (70\%) of students obtained $\mathrm{E}$ from the control group. 
Table 2: Mark grades comparison for the pre-tests of treatment and control groups

\begin{tabular}{ccccc}
\hline & \multicolumn{2}{c}{ Treatment Group } & \multicolumn{2}{c}{ Control Group } \\
Grade (Marks) & Frequency & Percentage (\%) & Frequency & Percentage (\%) \\
\hline C (50-64) & 4 & 12.1 & 5 & 16.7 \\
D (40-49) & 9 & 27.3 & 4 & 13.3 \\
E (0-39) & 20 & 60.6 & 21 & 70.0 \\
Total & 33 & 100 & 30 & 100 \\
\hline
\end{tabular}

Table 3 shows the $t$-test analysis of the pre-test marks by the control and treatment group. This analysis shows that the mean marks for the treatment group ( $M=36.05$ ) is not significantly different with the mean marks for the control group ( $M$ $=31.70$ ). Therefore, $\mathrm{Ho}_{1}$ is accepted. This analysis shows that the level of knowledge is the same for both groups and thus the respondents are similar in terms of knowledge level for both groups.

Table 3: The t-test for pre-test marks for treatment and control groups

\begin{tabular}{lccccc}
\hline Variable & $M$ & $S D$ & $t$ & $d f$ & $p$ \\
\hline Pre-test Marks & & & 1.3 & 61 & .198 \\
Treatment Group & 36.05 & 11.89 & & & \\
Control Group & 31.70 & 14.59 & & & \\
\hline
\end{tabular}

$\mathrm{Ho}_{2}$ : There is no significant difference between the post-test mean marks between the treatment group and the control group.

Table 4 shows the post-test marks comparison for the treatment and control groups. Five students (15.2) obtained grade $A$ in the treatment group while none got grade $A$ from the control group. None from the treatment group obtained an E while 8 studens (26.7) obtained an E from the control group.

Table 4: Marks Grade Comparison for Treatment and Control Groups

\begin{tabular}{ccccc}
\hline & \multicolumn{2}{c}{ Treatment Group } & \multicolumn{2}{c}{ Control Group } \\
Grade (Marks) & Frequency & Percentage (\%) & Frequency & Percentage (\%) \\
\hline A (80-100) & 5 & 15.2 & 0 & 0 \\
B (65-79) & 13 & 39.4 & 11 & 36.3 \\
C (50-64) & 10 & 30.3 & 10 & 33.3 \\
D (40-49) & 5 & 15.2 & 1 & 3.3 \\
E (0-39) & 0 & 0 & 8 & 26.7 \\
Total & 33 & 100 & 30 & 100 \\
\hline
\end{tabular}

T-test analysis towards the post-test for the treatment and control groups are shown on Table 5 . Findings show that the mean marks for the treatment group ( $M=62.67)$ is higher compared to the control group $(M=54.38)$. The analysis also showed that the mean marks for the treatment group is significantly different with the control group, $t(61)=2.11, p=.039$. Therefore, $\mathrm{HO}_{2}$ is rejected. There is significant difference between the mean marks of post-test for the treatment and the control groups.

Table 5: T-test analysis for the post-tests for the treatment and control groups

\begin{tabular}{lccccc}
\hline Variables & $M$ & $S D$ & $t$ & $d f$ & $p$ \\
\hline Post-test marks & & & 2.11 & 61 & .039 \\
Treatment Group & 62.67 & 13.70 & & & \\
Control Group & 54.38 & 17.41 & & & \\
\hline
\end{tabular}

$\mathrm{H}_{3}$ : There is no significant difference between the mean marks of the pre-test and the post-test of the treatment group.

Table 6 shows the paired t-test analysis for the different pre- and post-test marks obtained by the respondents in the treatment group. The finding shows that the mean score for the post-test is significantly different with the mean score of the pre-test, $, t(32)=11.35, p=.001$. Therefore, $\mathrm{H}_{0}$ is rejected. There is significant difference between the mean marks of the pre- and post-tests of the treatment group. 
Table 6: Paired $t$-test analysis pre-test marks of the treatment group

\begin{tabular}{lccccc}
\hline Variables & $M$ & s.d. & $t$ & $d f$ & $p$ \\
\hline Treatment Group & & & 11.35 & 32 & .001 \\
Pre-test & 36.05 & 11.89 & & & \\
Post-test & 62.67 & 13.70 & & & \\
\hline
\end{tabular}

From the findings, the first hypothesis is accepted, while the $\mathrm{Ho}_{2}$ and $\mathrm{H}_{0}$.was rejected. The findings show that there is significant difference between the mean marks for the treatment and control groups and the mean marks for the pre- and post-tests for the treatment group. The empirical data has proven the effectiveness of project based learning compared to the traditional learning.

\section{Discussion}

The treatment group that received the PoBL method has shown improvement in terms of knowledge level. Using this method has helped 33 students master the topic of Project Design and Production. Overall students succeeded in mastering the topic learnt and the number of students who are left out in the learning has decreased. The PoBL method showed higher performance within its students compared to those who followed the traditional learning method. In the first hypothesis, students from the treatment and control group showed similar levels of grades. This means that their available level of knowledge is the same. The students in both groups mostly obtained 0-39 marks in the pre-test. This shows that they have yet to obtain the needed knowledge on the topic to be learnt. The mean marks which are similar between the groups support that the history threat in this story be reduced.

For the second hypothesis $\left(\mathrm{H}_{2}\right)$, the students in the treatment group who received the PoBL method showed better grades compared to the control group. The number of students who obtained $A$ has increased by 5 and no students were reported getting $E$ for their grade. This findings show that the PoBL learning method has successfully increased the performance for all its students whereas the traditional method still allowed a few students to be left out from the lessons.

For the third hypothesis $\left(\mathrm{H}_{3}\right)$, from the analysis of students marks distribution, it can be said that there is an increase in mastery within students for the topic of Project Design and Production when 5 students obtained the highest score (80\%) and the students who made mistakes also decreased. This shows that the PoBL method can benefit students when majority of students show comprehension improvement in the taught topic.

Last but not least, findings support a few previous studies that stated that PoBL can improve the knowledge and the performance of students in learning (Kaldi, Filippatou \& Govaris 2011; Bell 2010; Pau Chai Hung 2009). Therefore, the findings of this study contribute to the knowledge in handling the gaps in the educational system in this country that is exam based. Besides that, this method can also increase teachers' knowledge on pedagogy besides traditional teaching methods. Therefore, the learning as shown through PoBL can potentially become a good alternative for teachers to be practiced in their instruction.

\section{Conclusion}

Based on finding of this study, it was found that the PoBL method has found to bring positive effects in the level of content knowledge content among students for the topic of Project Design and Production. Thus, teachers in general or KHB teachers specifically are encouraged to try this alternative method in their teaching and learning processes. However, there could be hindrance for this matter as teachers may lack the confidence for this method in terms of skills, techniques and resources. Therefore, it is suggested that $\mathrm{PoBL}$ training and courses are given to teachers in service. Besides that, at the tertiary education level especially for pre-service teachers at tertiary level needs to be exposed on the $\mathrm{PoBL}$ teaching techniques so that they are trained at the earlier stage. Follow-up studies need to be conducted to examine the effectiveness of this method in improving 21st century skills needed within students in the nation.

\section{Acknowledgement}

This material is based on a part of a work result that is supported by the Research University Grant Scheme (RUGS) under the Cost Centre of 9199916. Any opinion, findings, and conclusions or suggests stated in this material is from the author and does not necessarily illustrate the opinions of other parties. 


\section{References}

Bell, S. (2010). Project-based learning for the 21st century: Skills for the future. The Clearing House, 83, 39-43.

Boss, S. (2011). Project based learning: A short history. Retrieved Jan 21, 2014 from http://www.edutopia.org/project-based-learninghistory.

Brodi, J. (2008). Pelaksanaan pembelajaran berasaskan projek: Satu kajian kes. Jurnal Penyelidikan Pendidikan IPTAR, 99-119.

Buck Institute of Education. (2012). What is PBL? Retrieved Jan 21, 2014 from http://www.bie.org/about/what_is_pbl

Burlbaw, L. M., Ortwein, M. J., \& Williams, J. K. 2009. From the project method to stem project-based learning: the historical context in Capraro, in R. M. \& Slough, S. W. Project-based learning: an integrated science, technology, engineering, and mathematics (STEM) approach, 7-18.

Chon Min, K., Mat Rashid, A., \& Nazri, M. I. (2012). Teachers' understanding and practice towards thematic approach in teaching integrated living skills in Malaysia. International Journal of Humanities and Social Science, 2(23), $273-281$.

Doppelt, Y. (2003). Implementation and assessment of project-based learning in a flexible environment. International Journal of Technology and Design Education, 13, 255-272.

Filippatou, D., \& Kaldi, S. (2010). The effectiveness of project-based learning on pupils with learning difficulties regarding academic performance, group work and motivation. International Journal of Special Education, 25(1).

Grant, M. M. (2002). Getting a grip on project-based learning: Theory, cases and recommendations. Meridian: A Middle School Computer Technologies Journal, 5(1), 1-3.

Grant, M. M. (2011). Learning, beliefs, and products: Students' perspectives with project-based learning. Interdisciplinary Journal of Problem-based Learning, 5(2), 2.

Helle, L., Tynjala, P., \& Olkinuora, E. (2006). Project-based learning in post-secondary: Theory, practice and rubber sling shots. Higher Education, 51, 287-314.

Holubova, R. (2008). Effective teaching methods: Project-based learning in physics. US-China Education Review, 5(49), 12.

Kaldi, S., Filippatou, D., \& Govaris, C. (2011). Project-based learning in primary schools: Effect on pupils' learning and attitudes. Education, 39(1), 35-47.

Knoll, M. (1997). The project method: Its vocational education origin and international development. Journal of Industrial Teacher Education, 34(3), 59-80.

Larmer, J., \& Mergendoller, J. R. (2010). 7 Essentials for project-based learning. Educational Leadership. Alexandria, VA: Association for Sepervision \& Curriculum Development.

Markham, T., Larmer, J., \& Ravitz, J. (2003). Project based learning: A guide to standards-focused project based learning for middle and high school teachers. Navato, CA: Buck Institute for Education.

Mergendoller, J. R., Maxwell, N. L., \& Bellisimo, Y. (2006). The effectiveness of problem-based instruction a comparative study of instructional method and student characteristics. Interdisciplinary Journal of Problem-based Learning, 1(2), 5.

Ministry of Education. (2006). Project-based learning handbook: Educating the millenial learner. Retrieved on Feb 25, 2014 from http://www.moe.edu.my/btp/wp-content/uploads/2011/07/Project\%20Based\%20Learning\%20Handbook/2\%20-\%20Project\%20 Based\%20Learning\%20Handbook.pdf

Ministry of Higher Education. (2007). Kerangka pelan strategik. Retrieved Feb 24, 2014 from http://www.mohe.gov.my/transformasil images/Bab2.pdf

Ravitz, J. (2010). Beyond changing culture in small high schools: Reform models and changing instruction with project-based learning. Peabody Journal of Education, 85(3), 290-312.

Schu Pyng, H., \& Mat Rashid, A. (2014). Relationship between teachers teaching styles and students interest towards Integrated Living Skills subject in schools. Journal of International Education Research, 10(1), 7-14.

Thomas, J. W. (2000). A review of research on project-based learning. Retrieved Jan 15, 2014 from http://www.bie.org/research/ study/review_of_project_based_learning_2000.

Yueyu Xu, \& Wenqi Liu. (2010). A project-based learning approach: A case study in China. Asia Pacific Education Review, 11(3), 363370. 